\title{
Comparative Law and the Ad Hoc Tribunals: The Dangers of a Narrow Inquiry ${ }^{\dagger}$
}

\author{
ALDO ZAMMIT BORDA*
}

\begin{abstract}
This article focuses on the distinctions that the ad hoc Tribunals have drawn between the comparative law method and the review of evidence for clarifying customary international law and general principles of law. It outlines the dangers in the readiness of some international judges to accept narrow inquiries, which at best attach special weight and at worst restrict the scope of inquiry to a single, specific legal system. The readiness of some international judges to simply elevate legal rules and concepts with which they are familiar from their own legal education and practice to the level of universal truths may imply a failure to understand the other legal traditions on offer. The article concludes by showing that, unless the dangers inherent in the readiness to accept narrow inquiries are clearly emphasized, the achievement of an international criminal justice that is truly tolerant of plurality is a long way off.
\end{abstract}

\section{Introduction}

The former Israeli Supreme Court Chief Justice, Aharon Barak, describes comparative law as an "experienced friend." Although he makes this comment in relation to national jurisdictions, some judges at the UN International Criminal Tribunal for the former Yugoslavia and the UN International Criminal Tribunal for Rwanda (the "ad hoc Tribunals") ${ }^{2}$ have

$\dagger$ (C) 2012 Borda.

* BA, MEconSc, LLD. Currently PhD candidate at Trinity College, University of Dublin. Fellow of the Honourable Society of the Middle Temple. The author wishes to thank his supervisor, Dr Rosemary Byrne. He would also like to thank Dr. Robert P. Barnidge, Jr. All errors are the author's own. Email: zammitba@tcd.ie.

' Barak, 'Response to "The Judge as Comparatist: Comparison in Public Law"', 80 TUL. L. REV. (2005-2006) 195, at 196.

2 The UN International Criminal Tribunal for the former Yugoslavia ("ICTY"), established by the Security Council of the United Nations in 1993, pursuant to 
also seen the benefit of consulting this "experienced friend" in the course of their jurisprudence.

Particularly when international criminal law was still at a rudimentary stage of its development, ${ }^{3}$ international judges sometimes adopted a comparative law methodology and undertook a comparative analysis of legislation and case law. ${ }^{4}$ While acknowledging that comparative law can provide a fruitful point of reference, this article seeks to highlight the distinctions that the ad hoc Tribunals have drawn between the comparative law method and the review of evidence for elucidating customary international law and general principles of law.

This article begins by providing a brief overview of the descriptive and interpretive phases of the comparative law method before considering the points of interaction between national and international juridical spaces. It then discusses customary international law and general principles in the light of this method, finding that there is much to be gained from consulting the experience of comparative law. In the final section, the article considers instances in which the ad hoc Tribunals were ready to accept narrow inquiries and underscores the dangers with such an approach.

\section{Comparative Law and the Ad Hoc Tribunals}

\section{A. An Overview of Comparative Law}

resolution 808 of 22 February 1993 and resolution 827 of 25 May 1993 (U.N. Doc. S/RES/808(1993); U.N. Doc. S/RES/827 (1993); and the UN International Criminal Tribunal for Rwanda ("ICTR"), established by the United Nations Security Council by its resolution 935 of 8 November 1999 (UN Document SIRES1955 of 8 November 1994).

${ }^{3}$ Cassese, 'The influence of the European Court of Human Rights on international criminal tribunals - some methodological remarks', in M Bergsmo and A Eide, HUMAN RIGHTS AND CRIMINAL JUSTICE FOR THE DOWNTRODDEN: ESSAYS IN HONOUR OF ASBJøRN EIDE (2003), at 19.

${ }^{4}$ Admittedly, this may sometimes have been for instrumental reasons. Judge Cassese, the first president of the ICTY, stated: "Mon experience est que souvent le droit compare est utilise pour confirmer une solution que l'on avait déjà trouvée." See Cassese, during a round table talk, printed in CRIMES INTERNATIONAUX ET JURISDICTIONS INTERNATIONALES 140 (Mireille Delmas-Marty \& Antonio Cassese eds. (2002), cited in Bohlander and Findlay, 'The Use of Domestic Sources as a Basis for International Criminal Law Principles', in the GLOBAL COMMUNITY YEARBOOK OF INTERNATIONAL LAW AND JURISPRUDENCE (2002) 2, at 25. 
In 'The Science of Comparative Law', Schmitthoff holds that comparative law is characterized by a broad and fundamental distinction between "the activities concerned with the collation of facts and the utilization of the results gained by comparison. The first phase is mainly descriptive; it consists in examining the reaction of a number of legal systems to an individual legal problem. The second stage is concerned with the utilization of the results obtained in the first phase, and this utilization can be effected for a great variety of reasons."

The first phase of comparative law, according to Schmitthoff, assumes the existence of the following prerequisites: "First, the topic or topics under examination must be comparable, secondly, regard must be had to their legal and social background, and thirdly, an analytical classification of an impartial and purely scientific character must be applied to the matters under investigation."6

Establishing a basis of comparability for the relevant topics, such as a common underlying ideology, is a prerequisite of comparative law.

Schmitthoff states that comparative law has to confine itself to legal systems which have reached the same (comparable) level of evolution. ${ }^{7}$

Barak has argued that comparative law is not merely the comparison of laws and that a useful comparison can only exist if the legal systems being compared share a common ideological basis. ${ }^{8}$ Thus, with respect to democratic legal systems, a meaningful comparison could only be had with other democratic legal systems. ${ }^{9}$

Indeed, critics of comparative law are keen to emphasize the inherent incomparability of legal systems and some go to the extreme of denying that a sound basis of comparability can ever be established satisfactorily. A Hong Kong High Court judge, for instance, held that resort to foreign judgments should be eschewed because they were the product of very different

${ }^{5}$ Schmitthoff, 'The Science of Comparative Law', 7 CAMBRIDGE L.J. (19391941) 94 , at 95.

${ }^{6}$ Ibid., at 96 .

${ }^{7}$ Ibid.

${ }^{8}$ Barak, supra note 1 , at 196.

${ }^{9}$ Ibid. 
circumstances and situations. It was considered, therefore, that the systems were simply incomparable. ${ }^{10}$

While Schmitthoff characterizes the first phase of comparative law as mainly descriptive, requiring the collation of facts and their analytical classification to be of an impartial and purely scientific character, he recognizes that complete impartiality is, in practice, unattainable. Some degree of critical analysis is inevitable even at this early stage, conceding that the accumulation of facts is impossible without critical analysis."

It is clear that elements of subjectivity come into play the moment categories are drawn and critical, value-laden assessments relating to the collation of facts are made. While recognizing that some form of critical subjectivity is therefore inevitable, Schmitthoff holds that the reliability of the process ultimately depends on the tact and experience of the researcher. ${ }^{12}$

The second phase of comparative law relates to the interpretation and utilization of the results gained, with the ultimate aim being, inter alia, to enlarge the general knowledge of the law or, in the case of applied comparative law, to seek to improve one's own legal system, or to seek to avoid conflict, such as through the harmonization or unification of laws, or the development of model laws.

\section{B. Interaction Between the Domestic and International Juridical Spaces}

Ellis observes that international law has a good deal to learn from municipal legal systems, given the interdependence of domestic and international law in such areas as criminal liability. ${ }^{13}$ This interaction between national and international legal spaces has been at the heart of global criminal justice since at least the creation of the ad hoc Tribunals. ${ }^{14}$

${ }^{10} \mathrm{R}$ v Town Planning Board, ex parte Kwan Kong Ltd (1995) 5 HKPLR 261. Cited in McCrudden, 'A Common Law of Human Rights?: Transnational Judicial Conversations on Constitutional Rights', 20 OXFORD J LEGAL STUDIES (2000) 4, at 6.

"I Schmitthoff, supra note 5, at 99.

${ }^{12}$ Ibid.

${ }^{13}$ Ellis, 'General Principles and Comparative Law', 22 EUROPEAN J OF INT'L L. (2011) 4, at 949 .

${ }^{14}$ See Delmas-Marty, 'Interactions between National and International Criminal Law in the Preliminary Phase of Trial at the ICC', $4 J$ INT CRIMINAL JUSTICE (2006) 1 , at 2 . 
Both ad hoc Tribunals are bound to interpret and apply international law, as found in the formal sources of law enshrined in Article 38(1)(a) - (c) of the Statute of the International Court of Justice (ICJ), namely, international conventions, international custom, and general principles of law.

Moreover, with respect to rules of procedure and evidence, the judges at the ad hoc Tribunals were accorded substantial rule-making power. States accepted this as an inevitable corollary of the creation of the ad hoc Tribunals, given that they were created under great pressure and time constraints and for which no detailed procedural framework was formulated by the drafters of their constituent statutes. ${ }^{15}$ Through their powers to draft, amend and interpret rules of procedure and evidence, international judges act as both the architects and deliverers of the international criminal procedural system. ${ }^{16}$ This system has been particularly influenced by the common and civil law traditions, ${ }^{17}$ the two main legal traditions in the West. ${ }^{18}$

\section{The Application Of Comparative Law By The Ad Hoc Tribunals}

One author has observed that the attraction of comparative law stems from the sources of international criminal law, at least to the extent that custom and general principles of law are partly based on national law. ${ }^{19}$ This section will explore the interrelation between comparative law, on the one hand, and customary international law and general principles of law, on the other.

\section{Comparative Law and Customary International Law}

According to the International Court of Justice (the "ICJ"), the two material sources of customary international law are the practice and opinio

${ }^{15}$ Sluiter, 'Procedural Lawmaking at the International Criminal Tribunals', in Darcy and Powderly, JUDICIAL CREATIVITY AT THE INTERNATIONAL CRIMINAL TRIBUNALS (2010), at 315.

${ }^{16}$ Byrne, 'The new public international lawyer and the hidden art of international criminal trial practice', 25 CONNECTICUT J INT'L L. (2005) 243, at 248 and 259.

${ }^{17} \mathrm{Ibid}$., at 248 and 255.

${ }^{18}$ Picker, 'A Framework for Comparative Analyses of International Law and its Institutions: Using the Example of the World Trade Organization', in Cashin Ritaine, Donlan and Sychold (eds.), COMPARATIVE LAW AND HYBRID LEGAL TRADITIONS, 67 Publication of the Swiss Institute of Comparative Law (2009). Several of the author's views are applicable here, although he was writing in relation to the WTO.

${ }^{19}$ Delmas-Marty, 'The Contribution of Comparative Law to a Pluralist Conception of International Criminal Law', 1 J INT’L CRIM. JUSTICE (2003) 13. 
juris of States. ${ }^{20}$ The process of clarifying customary international law, therefore, requires reviewing evidence from, inter alia, national jurisdictions in order to make out these material sources. Both ad hoc Tribunals have frequently engaged in this process, particularly as the ICTY was expressly required, by the UN Secretary-General's report, ${ }^{21}$ to apply rules which were beyond any doubt part of customary international law.

The process of reviewing evidence in the context of clarifying the content of customary international law resembles Schmitthoff's first phase of comparative law, namely, the "collation of facts" phase. ${ }^{22}$ Indeed, on at least one occasion, the ad hoc Tribunals considered the processes of "review" and of "comparative analysis" as interchangeable. In Kunarac, the Trial Chamber had had recourse to various legislation and case laws in relation to the definition of rape. ${ }^{23}$ In describing this process, the ICTY Appeals Chamber in Kunarac termed it a "review":

127. After an extensive review of the Tribunal's jurisprudence and domestic laws from multiple jurisdictions, the [Kunarac] Trial Chamber concluded $[\ldots]^{24}$ (Emphasis added)

While the ICTR Trial Chamber in Semanza termed the same process a "comparative analysis":

345. While this mechanical style of defining rape was originally rejected by this Tribunal, the Chamber finds the comparative analysis in Kunarac to be persuasive... ${ }^{25}$ (Emphasis added)

In considering whether acts of looting constituted the specific offence of plunder, the ICTY Trial Chamber in Simic made reference to "comparative

${ }^{20}$ Continental Shelf (Libyan Arab Jamahiriya / Malta), ICJ REPORTS (1985), 29 30 , at 27.

${ }^{21}$ Paragraph 34 of the Report of the Secretary-General pursuant to paragraph 2 of Security Council resolution 808 (1993) and Annex thereto, U.N. Doc. S/25704.

${ }^{22}$ See supra, at 2.

${ }^{23}$ Prosecutor v. Dragoljub Kunarac, Radomir Kovac and Zoran Vukovic (2001), IT-96-23-T \& IT-96-23/1-T, ICTY Trial Chamber, at 447-456.

${ }^{24}$ Prosecutor v. Dragoljub Kunarac, Radomir Kovac and Zoran Vukovic (2002), IT-96-23 \& IT-96-23/1-A,

ICTY Appeals Chamber, at 127. at 345 .

Prosecutor v. Laurent Semanza (2003), ICTR-97-20-T, ICTR Trial Chamber, 
legal sources" in concluding that the two terms are generally used synonymously. ${ }^{26}$

In his Separate Opinion in Halilovic, Judge Schomburg considered that there was no need to engage in a "comparative legal analysis" with respect to the question of whether someone qualified as a suspect, as the statutory definition of the term was sufficiently clear. ${ }^{27}$

While it is undoubted that the collation of facts in the context of comparative law and the review of evidence in the context of customary international law share some important similarities, the two processes have to be distinguished.

Establishing a valid basis of comparability between the legal systems that are to be compared is a prerequisite of any comparative legal analysis. For instance, it is appropriate to recall Barak's argument that a useful comparison can only exist if the legal systems being compared share a common ideological basis. ${ }^{28}$ Furthermore, comparative law prescribes no minimum number of jurisdictions or systems to be compared. A meaningful comparative analysis can be had between just two or a few jurisdictions and the strength of the comparison depends, inter alia, on the comparability of those jurisdictions, such as whether they share a common ideological basis.

Article 38(1)(b) of the ICJ Statute, on the other hand, explicitly prescribes that, for the purposes of customary international law, evidence of a general practice has to be established. A review undertaken with the aim of clarifying the contents of customary international law has to be broad enough to provide evidence of an extensive and representative practice, although evidence that a practice is universal is not necessary. ${ }^{29}$ Contrary to

${ }^{26}$ The Trial Chamber also made use of linguistic sources. See Prosecutor v. Blagoje Simić, Miroslav Tadić, Simo Zarić (2003), IT-95-9-T, ICTY Trial Chamber, at 98 .

${ }^{27}$ Prosecutor v. Sefer Halilovic (2007), IT-01-48-A, ICTY Appeals Chamber, Separate Opinion of Judge Schomburg, at 4.

${ }^{28}$ Supra, at 2.

${ }^{29}$ See Henckaerts, 'Study on customary international humanitarian law: A contribution to the understanding and respect for the rule of law in armed conflict', 87 INT'L REV. OF THE RED CROSS (2005) 857, at 180. Although, "[i]t is settled that uniformity of acceptance or observance is not required for proof of the emergence of a new norm of customary international law, generality being enough." See Prosecutor v. Anto Furundzija (2000), IT-95-17/1-A, ICTY Appeals Chamber, Declaration of Judge Shahabuddeen, at 257. 
comparative law, therefore, the review of evidence from just two or a few jurisdictions would not, normally, be sufficient for customary international law.

Moreover, the establishment of a basis of comparability is not a prerequisite in customary international law. Indeed, in her review of evidence, in the context of clarifying customary international law, the international judge should not restrict her search to, for instance, only legal systems which share a common ideological basis. She is guided by the imperatives of extensiveness and representativeness.

Schmitthoff acknowledged that, in comparative analysis, some level of subjectivity was inevitable at the collation of facts phase. ${ }^{30}$ In undertaking comparative legal analysis with respect to a particular crime, for instance, the comparatist is not bound by the formal classification of this crime by the domestic criminal codes of States. The comparatist has the latitude to delve deeper and, having regard to the political, social and other context in the States under comparison, question whether the formal classifications are appropriate and/or whether other crimes, not formally classified as such, should also be included in the comparison. This is an inherently subjective exercise.

In reviewing the legislation and case law of, inter alia, national jurisdictions in search of evidence for the clarification of customary internationál law, the international judge undertakes an eminently empirical review. In conducting this review, the international judge is not primarily concerned with establishing a basis for comparison between the systems. She is not expected, for instance, to confine her search to systems which share a common ideological basis. Her main objective is rather to gather extensive and representative evidence that relates to the content of a rule of customary international law.

Given that the authority of the international judge to elucidate customary international law derives from State consent, she is not, unlike the comparatist who has far greater latitude in this regard, normally expected to second guess the formal, legal classifications of crimes by States or to undertake anything other than an impressionistic assessment of domestic legislation and case laws. The difference is therefore one of degree: the international judge is not expected to enter into the same level of critical analysis of legislation and case law as a comparatist. In her review of

\footnotetext{
${ }^{30}$ Supra, at 3.
} 
extensive and representative evidence to clarify customary international law, she is rather expected, generally, to accept domestic legal classifications at face value - without trying to second guess them. This is attested by Bohlander and Findlay who, in their research of early decisions of the ICTY, observe that "the judges in the Tribunal only quote the words of [domestic] legislation without interpreting and declaring their meaning.,"31

\section{Comparative Law and General Principles of Law}

Reflecting on general principles of law, Ellis contends that " $[\mathrm{t}] \mathrm{h}$ e vast scholarship on comparative law seems to have had little influence on most international jurists contemplating general principles of international law." 32 She asserts that comparative scholarship provides a rich source of guidance for international judges with respect to general principles of law. ${ }^{33}$

In identifying general principles of law, Cassese sets forth the following conditions:

(i) unless indicated by an international rule, reference should not be made to one national legal system only, say that of common-law or that of civil-law States. Rather; international courts must draw upon the general concepts and legal institutions common to all the major legal systems of the world. This pre-supposes a process of identification of the common denominators in these legal systems so as to pinpoint the basic notions they share;

(ii) since 'international trials exhibit a number of features that differentiate them from national criminal proceedings' [reference is made here to Judge Cassese's Separate and Dissenting Opinion in Erdemovic, 7 October 1997], account must be taken of the specificity of international criminal proceedings when utilising national law notions. In this way a mechanical importation or transposition from national law into international criminal proceedings is avoided, as well as the attendant distortions of the unique traits of such proceedings (para. 178). ${ }^{34}$

${ }^{31}$ Bohlander and Findlay, supra note 4, at 16.

${ }^{32}$ Ellis, supra note 13 , at $949-951$.

${ }^{33}$ Ibid.

${ }^{34}$ Cassese, 'The Contribution of the International Criminal Tribunal for the Former Yugoslavia to the Ascertainment of general Principles of Law Recognized by the Community of Nations', in Sienho Yee and Wang Tieya (eds.), INTERNATIONAL LAW IN THE POST-COLD WAR WORLD - ESSAYS IN MEMORY OF LI HAOPEI (2001). 
While the process of identifying general principles of law, like that of reviewing evidence for customary international law, may appear similar to the process of collating facts in the context of comparative law, there are, even here, some important distinctions.

Fundamentally, the method of identifying general principles is premised on the principle of representativeness. ${ }^{35}$ For instance, the ICTY Appeals Chamber in Kupreskic made it clear that the threshold for identifying general principles of law is high, in the sense that it needed to be shown that the principle was part of most, if not all, national legal systems. ${ }^{36}$ Such a high threshold of representativeness is not generally a requirement of comparative law.

In reviewing the legislation and case laws of national jurisdictions in order to identify (or, indeed, to rule out) a general principle of law, the international judge is guided by imperatives of representativeness. Again, establishing a basis of comparability is not a prerequisite in the process.

This is bolstered by the fact that, although Article $38(1)(\mathrm{c})$ of the ICJ Statute still formally requires international judges to direct their attention towards general principles of law recognized by civilized nations, it is widely accepted that this qualification has become redundant, and reference to "civilized" nations is now broadly understood to mean all nations. ${ }^{37}$

Therefore, the criterion of "civilized", which may have provided a possible basis for comparison, has given way to the imperative of representativeness.

Judge Shahabuddeen observed, in his declaration in the Furundzija appeal, that general principles of law were:

not so much generalizations reached by application of comparative law ... as particularizations of a common underlying sense of what is just in the circumstances. ${ }^{38}$

${ }^{35}$ Ellis, supra note 13 , at $953-954$.

${ }^{36}$ See Nollkaemper, 'Decisions of National Courts as Sources of International Law: An Analysis of the Practice of the ICTY', in G Boas and W Schabas, INTERNATIONAL CRIMINAL LAW DEVELOPMENTS IN THE CASE LAW OF THE ICTY (2003), at 287.

${ }^{37}$ See, for instance, Shirley V. Scot, INTERNATIONAL LAW IN WORLD POLITICS: AN INTRODUCTION (2n Ed.) (2010), at 11.

${ }^{38}$ Furundzija, Declaration of Judge Shahabuddeen, supra note 29, at 260. 
While a comparatist may seek to extract the "essence of rules", 39 an international judge, in drawing upon national principles for the purpose of identifying general principles of law, seeks out the "common underlying sense" of justice rather than the "essence" of the principles. The identification of general principles of law is not arrived at on the basis of a lowest common denominator formula but, rather, on the basis of justice and morality. ${ }^{40}$ The international judge does not, therefore, seek to establish the "commonality" or "essence" of a set of principles, rather, she seeks to determine, on the basis of a representative set of national principles, what the interests of justice require in the particular circumstances of the case. The process is juridical rather than technical.

It may be in this sense that Cassese notes “... although the search for and the identification of a general principle can be accomplished by academics, it is only after such a principle has been legally found, through an appropriate and cogent legal reasoning, by a court of law that its existence can no longer be questioned. $" 41$

In her article, Ellis asserts that, if general principles are to be a viable source of law in a heterogeneous society, this source will have to be rethought. ${ }^{42}$ She holds that representativeness should be removed as a requirement for the identification of general principles and suggests, rather, that these should be grounded in the soundness and persuasiveness of legal argumentation:

This would mean that the validity of a general principle would have to be grounded in the soundness and persuasiveness of legal argumentation rather than in claims about the objective nature of law or implicit State consent. ${ }^{43}$

This argument is premised on a perception of general principles as mere generalizations, rather than, as Judge Shahabuddeen notes, particularizations of a common underlying sense of what is just in the circumstances.

${ }^{39}$ Ellis, supra note 13 , at 949 . The author notes that some comparatists doubt "the possibility of isolating the essence of a legal rule", ibid., at 959.

${ }^{40}$ Furundzija, Declaration of Judge Shahabuddeen, supra note 29, at 260.

${ }^{41}$ Cassese, supra note 34.

${ }^{42}$ Ellis, supra note 13 , at 971 .

${ }^{43}$ Ellis, supra note 13 , at 971 . 
Ellis recognizes that much of the controversy surrounding general principles relates to their underlying sources of validity, in that, recourse to general principles has sometimes been tainted with charges of judicial lawmaking. ${ }^{44}$ However, the alternative she advances is likely to exacerbate such controversy, because she proposes to do away altogether with the requirement of representativeness, which helps to preserve some degree of objectivity in the process and, rather, to ground general principles merely in the persuasiveness of the legal arguments of international judges. ${ }^{45}$

According to this approach, general principles would emanate from sound and persuasive legal arguments, without there being any reference to whether these arguments are representative or whether they reflect the position of just one or a handful of jurisdictions.

\section{Conclusion}

With the above qualifications in mind, international judges have seen the usefulness of drawing on the experience of comparative law in arriving at a better understanding of customary international law and general principles of law. For instance, in his dissent in Simic, Judge Schomburg drew extensively on the Comparative Analysis of Legal Systems ${ }^{46}$ carried out by the Max-Planck-Institut für ausländisches und internationales Strafrecht to provide an understanding of which States include co-perpetratorship in their criminal codes. $^{47}$

\section{Reflections on the Acceptance of Narrow Inquiries}

Judge Shahabuddeen has observed that "it should be recalled that international criminal law has not quite gone through the early phase of general international law, when the latter borrowed with relative freedom

${ }^{44}$ Ellis, supra note 13 , at $949-950$.

${ }^{45}$ Ellis, supra note 13 , at 971 .

${ }^{46}$ Participation in Crime: Criminal Liability of Leaders of Criminal Groups and Networks,

Expert Opinion, Commissioned by the United Nations - International Criminal Tribunal for the Former

Yugoslavia, Office of the Prosecutor- Project Coordination: Prof. Dr. Ulrich Sieber., Priv. Doz. Dr. Hans-Georg Koch, Jan Michael Simon, Max-Planck-Institut für ausländisches und internationales Strafrecht, Freiburg, Germany.

${ }^{47}$ Prosecutor v. Blagoje Simic (2006), IT-95-9-A, ICTY Appeals Chamber, Dissenting Opinion of Judge Schomburg, at 14. 
from West European domestic law."48 Judges at the ad hoc Tribunals have alternated, through judicial interpretation, between further propagating this influence and seeking to supplant it by reference to the sui generis nature of the ad hoc Tribunals.

In her consideration of the ICTY Appeal Chamber's approach in Erdemovic $^{49}$ in relation to the acceptance by the Tribunal of a guilty plea, Ellis notes that, "it was difficult to approach this matter from the point of view of general principles, because only common law systems know a guilty plea, and the judges could therefore not demonstrate the representativeness of any relevant principles. They concluded that reference could and should be had to common law adversarial systems from which the rule in the Statute was derived." She prefers this narrow inquiry, confined as it was to common law systems because it enabled the international judges to gain "insights generated by decades, even centuries, of collected experience at the municipal level." Indeed, she takes issue with Cassese for concluding that "such recourse was not permitted by law and, furthermore, was unacceptable."

On his part, Cassese objected to the strong tendency to refer to adversarial systems in seeking to interpret and apply the statute, arguing that the result would skew the ICTY's approach towards such systems. He found that all the guidance that the Tribunal required in considering a guilty plea could be found in the statute and rules of procedure. ${ }^{52}$

The ICTR Appeals Chamber in Rutaganda adopted a similar approach with respect to the scope of cross-examination. ${ }^{53}$ After noting that the rules of procedure and evidence gave little indication as to the scope of cross-examination and while underscoring that the ICTR was not bound by domestic rules of evidence, the Appeals Chamber noted that the ICTR's rules of procedure and evidence on cross-examination were patterned after the United States' Federal Rules of Evidence and held that the interpretation of

${ }^{48}$ Shahabuddeen, 'Judicial Creativity and Joint Criminal Enterprise', in S Darcy and J Powderly, JUdiCial CREATIVITY AT THE INTERNATIONAL CRIMINAL TRIBUNALS (2010), at 186.

${ }^{49}$ Prosecutor v. Erdemovic (1997), IT-96-22-A, ICTY Appeals Chamber.

${ }^{50}$ Ellis, supra note 13, at 969.

${ }^{51}$ Ibid.

${ }^{52}$ Ibid.

${ }^{53}$ Georges Anderson Nderubumwe Rutaganda v. The Prosecutor (2003), ICTR96-3-A, ICTR Appeals Chamber. 
some of these rules could indeed be guided by the domestic system after which they were patterned. ${ }^{54}$

In discussing the procedure for a motion for a judgement of acquittal after the close of the prosecution case, Michael and Findlay observe that in Jelisic, ${ }^{55}$ the ICTY Appeals Chamber took the view that this procedure has, with some exceptions, no real legislative equivalent in civil law systems. ${ }^{56}$ The Tribunal in this case was ready to accept a narrow inquiry and relied solely on common law sources which formally recognized such a procedure. Michael and Findlay, however, make the point that, had a more rigorous inquiry been undertaken, the Tribunal would have found that in some civil law States, such as Germany, "it is not exceptional for a judge in a criminal case, after having heard the prosecution evidence to tell the prosecution and the defence that he is not convinced beyond reasonable doubt of the prosecution case, that he does not need to hear the defence evidence at all, and intends to proceed to an acquittal at once." the Tribunal broadened the scope of inquiry on this question, the conclusion reached in practice may not have been different, "but it would be founded on a balanced and thoroughly researched basis." 58

The readiness of some judges at the ad hoc Tribunals to accept a narrow inquiry, which at best attaches special weight and at worst confined the scope of the review to a single, specific legal system, has not been limited to procedural rules only. Indeed, some judges have been ready to accept such a narrow inquiry in connection with the process of clarifying customary international law. For instance, with respect to the crime of conspiracy to commit genocide and the question of whether the agreement required for conspiracy must be formal and explicit, the ICTR Appeals Chamber in Nahimana, Barayagwiza and Ngeze referred exclusively to the national case law of the United States and the United Kingdom in concluding that such agreement need neither be formal nor explicit..$^{59}$

The ICTR Appeal Chamber's readiness to accept this narrow inquiry, confined as it was to the jurisprudence of only two, common law, jurisdictions can be contrasted with the partial dissent of Judge Shahabuddeen in the same

\footnotetext{
${ }^{54} \mathrm{Ibid}$, at $26-31$.

${ }^{55}$ Prosecutor v. Goran Jelisic (2001), IT-95-10-A, ICTY Appeals Chamber, at 30.

${ }^{56}$ Bohlander and Findlay, supra note 4, at 16-17.

${ }^{57}$ Ibid.

${ }^{58}$ Ibid

${ }^{59}$ Ferdinand Nahimana, Jean-Bosco Barayagwiza, Hassan Ngeze $v$ The Prosecutor (2007), ICTR-99-52-A, ICTR Appeals Chamber, at 894 - 899.
} 
case, who addressed an analogous question with extensive reference to both common law and civil law traditions. ${ }^{60}$

With respect to judicial interpretation, therefore, while the national legal traditions on which the articles and rules in question are modeled can provide some guidance, over-reliance on a narrow inquiry can lead to the perpetuation of the default position, according to which some international judges "interpret legal norms through the lexicons of their respective traditions," ${ }^{, 61}$ rather than through a truly sui generis prism. This contributes to the pervasive perception that some international judges simply "elevat[e] legal rules and concepts with which [they] are familiar from their own legal education and practice to the level of universal truths...". ${ }^{2}$

The argument may be made that, in accepting narrow inquiries, international judges are merely giving effect to the intention of the drafters of the statutes or rules of procedure, who may have borrowed a rule from a specific legal system. However, drafters' intent is only one of a number of possible approaches international judges may have recourse to when interpreting a statute. ${ }^{63}$ Moreover, an approach confined to a specific legal system tends to ignore the mandate of the ad hoc Tribunals to ensure international criminal procedure is not unduly influenced by a single legal tradition. $^{64}$

This point was underscored in Kordic where, in the context of interpreting rule $98 \mathrm{bis}(\mathrm{B})$ of the Statute, the Prosecutor referred to the proceedings under this rule as "no case to answer," using the description found in many common law jurisdictions. However, the Trial Chamber held:

...[T]he Chamber considers that the better approach is not to characterise Rule 98 bis proceedings in that way, lest it be thought that the Rule must necessarily be applied in the same way as proceedings for "no case to answer" in those jurisdictions. It is true that Rule 98bis proceedings, coming as they do at the end of the Prosecution's case,

${ }^{60}$ Ferdinand Nahimana, Jean-Bosco Barayagwiza, Hassan Ngeze v The Prosecutor (2007), ICTR-99-52-A, ICTR Appeals Chamber, Partly Dissenting Opinion of Judge Shahabuddeen, at $3-6$.

${ }^{61}$ Byrne, supra note 16, at 252.

${ }^{62}$ Ellis, supra note 13 , at 965 .

${ }^{63}$ Grover, 'A Call to Arms: Fundamental Dilemmas Confronting the Interpretation of Crimes in the Rome Statute of the International Criminal Court', 21 EUROPEAN J. OF INT'L L. (2010) 3, at 541.

${ }^{64}$ Bohlander and Findlay, supra note 33, at 23. 
bear a close resemblance to applications for no case to answer in common law jurisdictions. However, that does not necessarily mean that the regime to be applied for Rule 98 bis proceedings is the same as that which is applicable in the domestic jurisdictions of those countries. Ultimately, the regime to be applied for Rule 98bis proceedings is to be determined on the basis of the Statute and the Rules, having in mind, in particular, its construction in the light of the context in which the Statute operates and the purpose it is intended to serve. That determination may be influenced by features of the regime in domestic jurisdictions with similar proceedings, but will not be controlled by it; and therefore a proper construction of the Rule may show a modification of some of those features in the transition from its domestic berth. ${ }^{65}$

\section{Conclusion}

There may be broader risks related to the readiness of some international judges to accept a narrow inquiry and to elevate approaches and practices from a single legal tradition to the level of universal truths. One possible risk concerns the potential effects of an approach which focuses disproportionately on the experiences of Western liberal perspectives while overlooking those of emerging democracies. This was highlighted by Judge Meron's partial dissent in the Nahimana, Barayagwiza and Ngeze case. ${ }^{66}$ Judge Meron took issue with the Trial Chamber's finding that "hate speech that expresses ethnic and other forms of discrimination violates the norm of customary international law prohibiting discrimination." ${ }^{\text {"67 }}$ He reasoned that, although courts and commentators from Western liberal democracies can often be tempted, from an ex post perspective, to claim that no harm, and in fact much good, can come from the suppression of particularly odious ideas and hate speech, the reason for protecting hate speech lies in the ex ante benefits. The protection of speech, even speech that is unsettling and

${ }^{65}$ Decision on defence motions for judgment of acquittal, IT-95-14/2-T, Prosecutor v. Dario Kordic and Mario Cerkez, 6 April 2000 at 9. This reasoning was cited approvingly by the ICTY Appeals Chamber in Judgment, IT-95-10-A, Prosecutor v. Goran Jelisic, ICTY Appeals Chamber, 5 July 2001 , at 33.

${ }^{66}$ Although, admittedly, this case did not directly concern the acceptance by the ICTR Trial Chamber of a narrow inquiry. See Ferdinand Nahimana, Jean-Bosco Barayagwiza, Hassan Ngeze v The Prosecutor (2007), ICTR-99-52-A, ICTR Appeals Chamber, Partly Dissenting Opinion of Judge Meron.

${ }^{67}$ Ibid., at 5-12. 
uncomfortable, is important in enabling political opposition, especially in emerging democracies, to take root. ${ }^{68}$

A readiness to accept narrow inquiries may imply a failure to understand the other legal traditions on offer. This approach may also imply a failure to recognize that international trials exhibit a number of features that differentiate them from national criminal proceedings. ${ }^{69}$ Such an approach does not take account of the specificity of international criminal proceedings and risks distorting the existing differences and forcing uncomfortable compromises. Unless the dangers inherent in the readiness to accept narrow inquiries are clearly emphasized, in the words of Bohlander and Findlay, "then the achievement of an international criminal justice, resilient and tolerant of plurality is a long way off.",70

\footnotetext{
${ }^{68}$ Ibid., at 10 .

${ }^{69}$ Cassese, supra note 34.

${ }^{70}$ Bohlander and Findlay, supra note 4, at 26.
} 
Copyright of International Journal of Legal Information is the property of International Association of Law Libraries and its content may not be copied or emailed to multiple sites or posted to a listserv without the copyright holder's express written permission. However, users may print, download, or email articles for individual use. 